\title{
THE ROLE OF MENTORS IN LAND REFORM PROJECTS SUPPORTED THROUGH THE RECAPITALISATION AND DEVELOPMENT PROGRAMME: FINDINGS FROM BUFFALO CITY METROPOLITAN MUNICIPALITY, SOUTH AFRICA
}

\author{
Maka, L. ${ }^{1}$ and Aliber, M. A. ${ }^{2}$ \\ Correspondence author: L. Maka. Email: MakaL@arc.agric.za
}

\begin{abstract}
Since the beginning of South Africa's land reform programme in 1994, much concern has been expressed about the uneven performance of newly settled farmers, which has typically been explained by weak 'post-settlement support'. In 2009, the government launched the Recapitalisation and Development Programme (RADP) in order to assist farms that have received little or no support, especially land reform farms. One salient aspect of the RADP is that it links recipient farmers with strategic partners or mentors, often as a condition of receiving financial support. Qualitative research was conducted in the form of seven in-depth case studies of RADP-supported land reform projects, together with interviews with four RADP mentors and three government officials. Some of the challenges in the farms before RADP funding was received included little or no income, high mortality rate of livestock, and lack of skills. The study revealed that the RADP mentorship remains a vital practice to be considered in capacitating land reform beneficiaries. It is recommended that funds should be made available for mentors to have an agreement of at least three to five years in a single project.
\end{abstract}

Keywords: Land Reform, Mentors, Recapitalisation

\section{INTRODUCTION}

Land dispossession during the colonial era and the decades of apartheid rule produced a highly unequal pattern of land ownership and widespread rural poverty in South Africa (Jacobs, Lahiff \& Hall, 2003). In 1994, under the new government led by the African National Congress (ANC), South Africa embarked on an ambitious land reform programme with two broad objectives in mind, namely restorative justice and economic empowerment. Not only did the ANC envisage that land reform would create more opportunities for black people to farm, it expected black-owned farms to create large numbers of new employment opportunities, and stimulate rural development more broadly (ANC, 1994). However, even though government has transferred (or otherwise made available) approximately $10 \%$ of commercial farmland to black people, and spent almost R100 billion (at constant 2016 prices) in doing so, it is widely acknowledged that land reform has accomplished neither, as also emphasised by the former President Jacob Zuma in the 2017 State of the Nation Address (SONA, 2017).

According to the land audit by AgriSA, from 1994 to 2016 the available agricultural land had decreased by $4 \%$, from 97 million hectares to 93.3 million hectares. According to AgriSA

\footnotetext{
${ }^{19}$ Smallholder Agricultural Development, Agricultural Research Council, 1134 Park Street, Hatfield, Pretoria, 0083 .

${ }^{2}$ Department of Agricultural Economics and Extension, Faculty of Science and Agriculture, University of Fort Hare, South Africa, Private Bag X1314, Alice, 5700.
} 
(2017), this is attributed to the increased number of mines, industry and the expansion of towns and cities. The land audit suggests that both the state/ government and previously disadvantaged individuals own only $26.7 \%$ of the agricultural land.

Upon assuming the role of Minister of Department of Rural Development and Land Reform (DRDLR) in 2009, one of Gugile Nkwinti's (former Minister of DRDLR) first public announcements was that $90 \%$ of land reform projects up to then had failed. According to DRDLR (2013), it was identified that most land reform projects were not successful and were either in distress or had failed due to a lack of adequate and appropriate post-settlement support. In agreement, Jacobs (2003) stated that one of the main challenges affecting South Africa's land reform programme was the absence of effective post-settlement support. To remedy this, the former Minister further announced that his department would introduce the Recapitalisation and Development Programme (RADP). The RADP was launched in 2010 to assist farms, mainly but not exclusively land reform farms that were failing due to little or no support. One of the core elements of the RADP is to link recipient farmers to either strategic partners or mentors. The mentors are meant to provide support and guidance to these farmers.

According to Terblanché (2011), mentors use their experience to provide skills and knowledge through guidance, counselling and coaching. Murray (1991), as cited by Terblanché (2011), defines mentorship as a structure and series of processes designed to create effective mentoring relationships, guide the desired behaviour change of those involved, and evaluate the results for the protégés. Mentorship can be different from profession to profession and according to the workplace practices where it is implemented (Terblanché, 2011). Furthermore, strategic partnership, in the context of RADP, is a relationship between two commercial enterprises which is usually formalised by one or more business contracts. However, mentors and strategic partners have also been controversial. According to Hall and Kepe (2017), strategic partners and mentors receive tangible benefits, in other words mentors receive monthly cash payments from the state for playing this role, while strategic partners hold shares in joint ventures while benefiting from state subsidies and access to state land. In some provinces, the beneficiaries in these strategic partnership projects lack control over land, capital and production as compared to those that have mentors (Hall \& Kepe, 2017). According to an evaluation by Department of Performance, Monitoring and Evaluation (DPME, 2013), the poor selection and supervision of strategic partners is one of the factors that contributes to the poor performance of farmers in RADP projects. The main research question addressed in this article is how effective are mentors in capacitating beneficiaries with skills and knowledge?

\section{OVERVIEW OF THE RECAPITALISATION AND DEVELOPMENT PROGRAMME}

Jacobs (2003) argued that one of the main challenges affecting South Africa's land reform programme was the absence of effective post-settlement support. Ten years later, the Department of Rural Development and Land Reform was making the same point (DRDLR, 2013). According to Ellenson and Madhanpall (2014), the RADP was introduced as a strategic intervention to deal with these concerns. In other words, it was introduced in order to improve the sustainability of struggling land reform projects. Accordingly, the main objectives of the RADP are to increase production, guarantee food security, graduate emerging farmers to become commercial farmers, and create jobs opportunities within the agricultural sector. 
A key aspect of the RADP was to arrange for the assistance of strategic partners or mentors, who are meant to enhance farmers' skills and help them graduate to commercial farmer status. According to DRDLR (2015):

The mentor shall continuously assess the skills of the grant recipient and shall accordingly mentor, train and develop the skills of the grant recipient in order to enhance the grant recipient's proficiency as a commercial farmer.

Table 1 shows statistics for the RADP from its inception to the year 2014.

Table 1: RADP Statistics (November 2010 - March 2014)

\begin{tabular}{|l|c|c|c|c|c|c|c|}
\hline \multicolumn{1}{|c|}{ Province } & Projects & Hectares & Mentors & $\begin{array}{c}\text { Strategic } \\
\text { partners }\end{array}$ & Beneficiaries & $\begin{array}{c}\text { Farmers } \\
\text { trained }\end{array}$ & $\begin{array}{c}\text { Total } \\
\text { expenditure } \\
\text { (R mn) }\end{array}$ \\
\hline Eastern Cape & 188 & 111591 & 44 & 41 & 3385 & 125 & R427 \\
\hline Free State & 182 & 134587 & 34 & 44 & 1340 & 67 & R386 \\
\hline Gauteng & 115 & 19916 & 20 & 11 & 524 & 0 & R203 \\
\hline $\begin{array}{l}\text { KwaZulu- } \\
\text { Natal }\end{array}$ & 212 & 131619 & 38 & 66 & 8118 & 493 & R508 \\
\hline Limpopo & 196 & 79143 & 61 & 6 & 3319 & 197 & R339 \\
\hline Mpumalanga & 206 & 165726 & 55 & 33 & 5778 & 215 & R515 \\
\hline $\begin{array}{l}\text { Northern } \\
\text { Cape }\end{array}$ & 81 & 464914 & 28 & 22 & 740 & 109 & R201 \\
\hline North West & 215 & 225571 & 13 & 80 & 2158 & 69 & R425 \\
\hline $\begin{array}{l}\text { Western } \\
\text { Cape }\end{array}$ & 64 & 47714 & 5 & 11 & 2764 & 614 & R134 \\
\hline \begin{tabular}{l} 
TOTALS \\
\hline
\end{tabular} & $\mathbf{1 4 5 9}$ & $\mathbf{1 3 8 0}$ & $\mathbf{2 9 8}$ & $\mathbf{3 1 4}$ & $\mathbf{2 8 1 2 6}$ & $\mathbf{1 ~ 8 8 9}$ & R3 318 \\
\hline
\end{tabular}

Source: DRDLR, 2015

As of 2014, there had been 1459 RADP projects covering 1.4 million hectares and 28000 beneficiaries. Almost 300 mentorships had been put in place, and slightly more strategic partnerships. Projects that did not have mentors or strategic partners were assigned to project managers from DRDLR, who took responsibility for their monitoring. Mentors and strategic partners believe that their role is to guide the beneficiaries to grow and become independent farmers, which is important especially since beneficiaries do not have the necessary knowledge and would not be able to manage the RADP funds (DPME, 2013). From 2015, DRDLR recruited agricultural graduates to assist the land reform projects in the country that did not need partnerships, but more technical assistance for day-to-day operations. These agricultural graduates appear to be expected to perform similar roles to that of mentors.

\section{METHODOLOGY}

This study utilised in-depth case studies of seven RADP-supported land redistribution projects in Buffalo City Metropolitan Municipality (BCMM). These projects (details given in Table 2) were drawn from the 18 Land Redistribution for Agricultural Development (LRAD) and Proactive Land Acquisition Strategy (PLAS) projects that had received support from the RADP by 2016. These seven projects ranged from the production of various types of livestock to 
vegetable farming. Interviews were conducted using semi-structured questionnaires. In addition, key informant interviews were conducted with purposively selected mentors and government officials. Qualitative data from the survey were analysed using thematic analysis. The table below summarises the case study projects.

Table 1: Project summary

\begin{tabular}{|l|l|l|l|l|l|l|l|}
\hline \multicolumn{1}{|c|}{$\begin{array}{c}\text { Project } \\
\text { Name }\end{array}$} & $\begin{array}{c}\text { Farm } \\
\text { Size } \\
\text { (Ha) }\end{array}$ & $\begin{array}{c}\text { Total } \\
\text { number } \\
\text { of bene- } \\
\text { ficiaries }\end{array}$ & $\begin{array}{c}\text { Number } \\
\text { of active } \\
\text { bene- } \\
\text { ficiaries }\end{array}$ & $\begin{array}{c}\text { Year } \\
\text { farm } \\
\text { acquired }\end{array}$ & $\begin{array}{c}\text { Programme } \\
\text { type }\end{array}$ & $\begin{array}{c}\text { RADP } \\
\text { funds } \\
\text { received } \\
\text { (in } \\
\text { Rands) }\end{array}$ & $\begin{array}{c}\text { Main } \\
\text { commodity }\end{array}$ \\
\hline Beacon Hill & 146 & 2 & 2 & 2008 & PLAS & $\begin{array}{l}\text { R6 398 } \\
000\end{array}$ & Pigs \\
\hline $\begin{array}{l}\text { High Heaven } \\
\text { Farm }\end{array}$ & 67 & 10 & 2 & 2008 & LRAD & $\begin{array}{l}\text { R631 } \\
965\end{array}$ & Broilers \\
\hline $\begin{array}{l}\text { BN Zuma/ } \\
\text { Sea View }\end{array}$ & 24 & 5 & 4 & 2008 & PLAS & $\begin{array}{l}\text { R3 861 } \\
133\end{array}$ & $\begin{array}{l}\text { Tomatoes } \\
\text { and Broilers }\end{array}$ \\
\hline $\begin{array}{l}\text { Izandlazethu } \\
\text { farming CC }\end{array}$ & 202 & 7 & 5 & 2006 & LRAD & $\begin{array}{l}\text { R5 000 } \\
000\end{array}$ & Cattle \\
\hline $\begin{array}{l}\text { Wattle } \\
\text { Grove/Africa } \\
\text { n Ambition }\end{array}$ & 15 & 1 & 1 & 2008 & LRAD & $\begin{array}{l}\text { R2 481 } \\
233\end{array}$ & Tomatoes \\
\hline $\begin{array}{l}\text { Siyavuselela } \\
\text { Agric. Co-Op }\end{array}$ & 23 & 5 & 4 & 2008 & PLAS & $\begin{array}{l}\text { R6 000 } \\
000\end{array}$ & Tomatoes \\
\hline $\begin{array}{l}\text { Sixoweni } \\
\text { Trading } \\
\text { Enterprise }\end{array}$ & 83 & 1 & 1 & 2009 & PLAS & $\begin{array}{l}\text { R2 760 } \\
000\end{array}$ & Tomatoes \\
\hline
\end{tabular}

Source: Research findings, 2016

\section{FINDINGS}

\subsection{Beneficiaries' perspectives}

The researchers aimed to investigate the role of mentors as understood and as experienced by the beneficiary farmers. One of the seven selected projects was Beacon Hill, which is a pig project with an extent of 146 hectares in Mooiplaas, an area just outside of East London. The two beneficiaries on the farm are a married couple. When the RADP funds of R6.4 million were approved in 2013, they were transferred to the beneficiaries' joint account. The funds were used to buy a tractor, bakkie, office equipment, water tanks, and an electricity transformer, and also to repair a borehole and build piggery structures.

Another project selected was High Heaven Farm, a livestock and vegetable farm of 67 hectares. The farm was acquired in 2008 through LRAD for R13.7 million. The project is in Macleantown with 10 beneficiaries from a single household, but only two members are actively involved in the project. Previously, the woman who became the main beneficiary of the project farmed a 3.5 hectare plot in Berlin (an area just outside East London), which was too small to allow her to farm full-time. When she and her group managed to acquire High Heaven Farm 
closer to East London, she was able to abandon her career as a nurse. Prior to applying and receiving RADP funds, the project secured money through grants and loans from Old Mutual's Masisizane Fund and from the Eastern Cape Provincial Cooperative Development Fund of the Eastern Cape Development Corporation (ECDC). The project beneficiaries received RADP funds of R631 965 in 2012. The funds were used to overcome challenges that they were facing, such as the high mortality rate of broilers. In 2009, the area experienced a drought that affected their production as the dams and boreholes dried up and they were forced to buy water from the municipality. However, even though there were challenges, they acknowledged the assistance from RADP which allowed them to resuscitate their agricultural operations.

According to the beneficiaries interviewed, they were required by DRDLR to have mentors in order to receive the RADP funds. However, the role of mentors as perceived by beneficiaries was not only to allow access to funding, but to provide skills and knowledge about farming and management, and to facilitate access to markets. It was established that most of the beneficiaries were aware of their limitations as farmers, and welcomed the idea of having a mentor who could advise and inform them. The farmers also acknowledged the mentors' assistance in linking them to markets. Beneficiaries from four of the seven projects were unambiguously satisfied with their mentors. These respondents mostly stressed that they learned a lot from their mentors regarding farming strategies and techniques. The following quotations illustrate the perceptions of satisfied beneficiaries:

"As old people the mentorship programme has assisted us a lot. Times are changing so we also need to be equipped with new technology."

"Before our mentor arrived I did not know how to plant cash crops because we focused mostly on livestock production. I'm happy and confident now because I gained more knowledge on planting of crops and how to apply fertilisers."

"I appreciated the guidance from the mentor as the farming venture was healthy; we still call each other even today. I share my plans with him for his advice. I appreciate the experience and training I've received through my mentor."

"We still wish the contract between the mentor and the Department existed for much longer period than a year. We feel there is a lot we still need to learn from him."

Some of these respondents showed not just appreciation of how the mentorship programme impacted their farming, but also indicated that they had developed good relationships with their mentors. The last quote also points to an issue that in fact was voiced by a number of the other beneficiaries, namely that the duration of the mentorship was too brief.

Furthermore, beneficiaries from the three other projects were not satisfied with their mentors. The beneficiaries who were dissatisfied with their mentors felt that having a mentor was a waste of their time. As one beneficiary said:

"Having a mentor was a waste of money and my time, it seemed like one wanted to prove to the other who knows best."

Other beneficiaries indicated that a mentor should not behave like a boss, rather a person who is there to assist. In this regard, one beneficiary said:

"My mentor lived far from my farm, he would come fortnightly or even once a month and expect us to run around and accept everything he tells us to do."

What accounts for the divergent views amongst beneficiaries regarding their mentors? One factor is that beneficiaries differed in terms of their need for this type of assistance. In 
particular, those who had been farming for a relatively long period of time already felt that they did not need a mentor. However, it also seemed to be the case that black mentors were more appreciated than white mentors, although it is not clear why. Farmers also seemed to prefer more experienced mentors, but a few mentioned they also prefer younger mentors who are knowledgeable about technology or who will be able to adapt to changing technology as conditions change and production practices are refined.

\subsection{Perspectives of mentors}

The four mentors interviewed were males who had at least some tertiary education and were farmers who arguably would understand the challenges faced by the beneficiaries. Three of the four mentors mentioned that they had qualifications in Agricultural Extension, which they all agreed assisted them in creating a smooth and good relationship between themselves and the beneficiaries. One mentor stated:

"Agricultural extension is very broad and it starts from understanding a person before you can even share information with them so that you can know how to behave around that person."

Another mentor mentioned that:

"Some of the most important skills and techniques recognised and observed by those with extension knowledge is situation analysis and acknowledgement of indigenous knowledge. These help you to share correct skills according to the needs of people at the same time acknowledging what the beneficiaries already know."

Other characteristics that may be considered to be a good mentor include demonstrating a positive learning attitude as a mentor, and showing appreciation for mentees' views. One mentor expressed views on the characteristics of a mentor as follows:

"A mentor must be able to get along with other people with good commended track record that is traceable. They must be able to identify fears and misunderstandings with their mentees and identify perceptions that could hamper progress in the farm."

Another mentor said:

"A good mentor shall be able to establish expectations from both mentor and mentee and also agree on realistic goals that will improve production."

Two mentors mentioned that they were already in the Department's database because of the previous programmes they worked on for the Department. The other two mentors indicated that they were approached by the beneficiaries since they know them. All four interviewed mentors mentioned that they have only mentored one land reform project each and one mentioned that he has mentored two farms for two years.

According to the RADP funding model, the RADP's financial contribution to the farm decreases over the typical five-year timeframe and it is expected that the mentor's involvement will continue through the full five years. However, all the mentors mentioned that their contracts for each project were only for one year and agreed that the ideal time for mentorship is between five and 10 years. This is evidenced by one mentor who said:

"You cannot expect a farmer to learn all the necessary skills within a year unless you want them to fail." 
Another mentor mentioned that:

"The beneficiary and I went back and forth for the whole year trying to adjust and fix the business plan as we wanted to make it an operational plan, it was pity that as the contract ended there was not much done to that farm as he acquired it with nothing but only an old house."

All mentors indicated that the mentoring period was insufficient to capacitate the farmers with all the necessary skills to successfully run a productive farm. However, they mentioned that they tried to share all the important skills within that short period of time. The main skills that mentors shared with beneficiaries included business management skills, organisational skills, people skills, health awareness, technical knowledge, communication skills, time management, and farm management. Mentors emphasised that before skills are transferred and training is conducted, there should be an establishment of trust and relationship building between mentor and mentee.

When asked about the biggest challenges observed within the land reform projects being supported, the mentors highlighted the following:

Love affairs - The beneficiaries tend to become romantically involved with other members of the same group or project. This is seen as detrimental to the project as romantic relationships cause complications and conflicts that could have been avoided. One mentor mentioned that:

"These relationships are able to change the way of thinking, approach, and behaviour which affects their professional life and in most cases their performance as a group decreases."

Lack of agricultural knowledge - Mentors mentioned that some of the beneficiaries have little knowledge of agriculture. This is difficult for the mentor to remedy given that their mentorship contracts are usually for only one year.

Government officials' understanding of agriculture - One mentor indicated that some officials from the Department do not understand the practical part of agriculture, but rather that their knowledge is mostly based on theory. This runs the risk of having them not consider the same aspects that a farmer would when making decisions.

RADP funding - There are two main issues that are alarming to the mentors regarding the funding associated with the RADP, namely the gap in time between tranches, and beneficiaries requesting and buying unnecessary items. Mentors mentioned that the time the beneficiaries have to wait between tranches delays the process of production. This is exacerbated by the fact that some beneficiaries insist on buying items that are not required for improving production. The researcher also observed that on one of the farms, the beneficiaries started by building office spaces and buying office materials before they were even operational. As one mentor said:

"A farm is not a guesthouse or a hotel, it is a place to work. It is saddening to see that beneficiaries want to spend all their Recap funds in renovating their farm houses and turn them into luxury houses and the Department entertains that. Money should be invested in what will bring returns."

According to the findings of this study, mentors identify the following as their roles and responsibilities as mandated by DRDLR: implementation of RADP according to business plans, linking farmers to markets, empowering beneficiaries through technical skills transfer, 
monitoring expenditure according to business plans and ensuring the sustainability of the farms.

According to the key informants interviewed for the study, there were different strategies to advertise the mentorship programme. They were called to a meeting through their farming associations, contacted through the Department's database, and advertised through local newspapers. Upon appointment of mentors, both the mentor and the beneficiary needed to sign legal contracts, in particular the "RADP grant and skills development schedule of standard terms and conditions: Mentorship agreement".

\section{CONCLUSION AND RECOMMENDATIONS}

Mentorship remains a vital practice to be considered in capacitating land reform beneficiaries according to their needs and skills, such as farm and/ or business management, and technical knowledge. According to the mentors interviewed, a mentor should be someone who is eager to transform beneficiaries to be better farmers, and who has an up-to-date knowledge of agricultural technology and skills. Beneficiaries also need to promote a healthy relationship between themselves and the mentors by availing themselves and being willing to learn and cooperate. Even though there were mostly positive responses from the beneficiaries, some were unsatisfied with their mentors. They were concerned by the non-effectiveness of mentors in their lives since some mentors do not understand their roles and responsibilities. Although some were not satisfied by their mentors, this does not mean that they do not need them, but rather need good mentors who will understand their needs. It is recommended that the funds should be made available for mentors to have an agreement of not less than two years, but preferably three to five years in a single project.

\section{REFERENCES}

AFRICAN NATIONAL CONGRESS (ANC), 1994. Reconstruction and Development Programme: A policy framework. Johannesburg, South Africa.

AGRISA, 2017. Land audit: A transactional approach. Pretoria, South Africa.

DEPARTMENT OF PERFORMANCE, MONITORING AND EVALUATION (DPME), 2013. Implementation evaluation of the recapitalisation and development programme (from its inception in 2010 to June 2013) [viewed 10 March 2016]. Available from: http://evaluations.dpme.gov.za/evaluations/407

DEPARTMENT OF RURAL DEVELOPMENT AND LAND REFORM (DRDLR), 2013. Revised Policy for Recapitalisation and Development Programme of the Department of Rural Development and Land Reform. Pretoria, South Africa.

DEPARTMENT OF RURAL DEVELOPMENT AND LAND REFORM (DRDLR), 2015. RADP grant and skills development schedule of standard terms and conditions: Mentorship arrangement. Pretoria, South Africa.

ELLENSON, T. \& MADHANPALL, A., 2014. Impact of recapitalisation and development funding in the South African sugar industry. In Proceedings of the Annual Congress South African Sugar Technologists' Association, Vol. 87, pp.91-102.

HALL, R. \& KEPE, T., 2017. Elite capture and state neglect: New evidence on South Africa's land reform. Rev. Afr. Polit. Econ., 44(151):122-130. 
JACOBS, P., 2003. Post-transfer support in South Africa's Land Reform Programme. Programme for Land and Agrarian Studies (PLAAS). Cape Town, South Africa.

JACOBS, P., LAHIFF, E. \& HALL, R., 2003. Land redistribution. Programme for Land and Agrarian Studies (PLAAS). Cape Town, South Africa.

MURRAY, M., 1991. Beyond the myths \& magic of mentoring: How to facilitate an effective mentoring process. San Francisco: Jossey-Bass.

STATE OF THE NATION ADDRESS (SONA), 2017. The year of Oliver Reginald Tambo: Together we move South Africa forward [viewed 11 May 2017]. Available from: https://www.gov.za/SONA2017

TERBLANCHÉ, S.E., 2011. Mentorship a key success factor in sustainable land reform projects in South Africa. S. Afr. J. Agric. Ext., 39(1):55-74. 
